
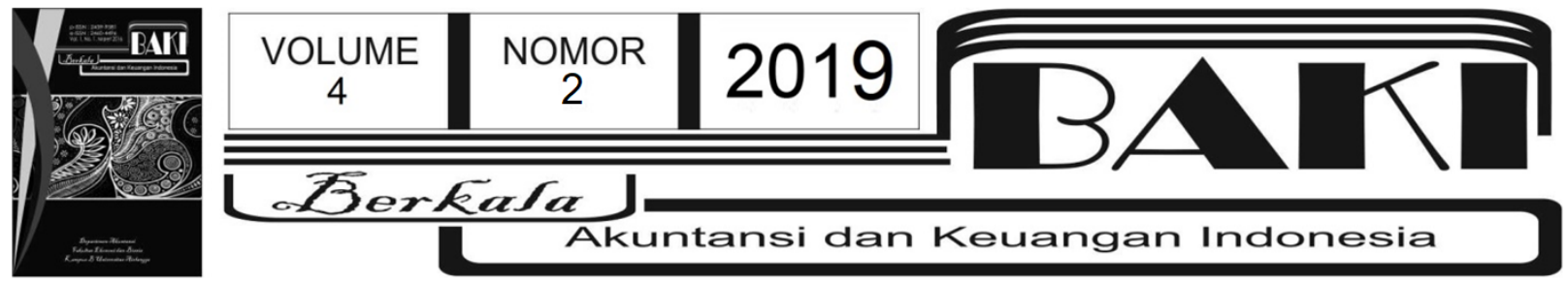

\title{
Pengaruh Karakteristik Manajemen Kinerja Terhadap Kinerja Aparatur Pemerintah
}

\author{
Erina Sudaryati ${ }^{1,2}$ \\ Dhikawidya Nugraha ${ }^{1}$
}

${ }^{1}$ Fakultas Ekonomi dan Bisnis Universitas Airlangga Surabaya
${ }^{2}$ erina.sudaryati@feb.unair.ac.id

INFO ARTIKEL

Histori Artikel:

Tanggal Masuk 30 Oktober 2019

Tanggal Diterima 1 Desember 2019

Tersedia Online 31 Desember 2019

\section{Kata Kunci:}

Sistem manajemen kinerja, karakteristik sistem manajemen kinerja, kinerja aparatur

\begin{abstract}
ABSTRAK
Kemunduran atau rendahnya kepercayaan publik terhadap institusi pemerintah menjadi masalah mendasar di Indonesia maupun negara-negara maju. Kemunduran kepercayaan tersebut terjadi antara lain karena maraknya kasus korupsi yang dilakukan pejabat publik maupun ketidaksesuaian layanan yang diberikan terhadap harapan masyarakat. Untuk mengatasi hal tersebut maka diperlukan adanya upaya yang dilakukan pemerintah untuk mengembalikan kepercayaan publik terhadap institusi pemerintah. Penerapan sistem manajemen kinerja dapat menjadi salah satu upaya guna meningkatkan kinerja aparatur dan mengembalikan kepercayaan publik terhadap institusi pemerintah. Sistem manajemen kinerja yang efektif harus ditunjang dengan karakteristik sistem manajemen kinerja yang baik. Penelitian ini berfokus pada karakteristik performance management system activities dan structure of performance management systems. Penelitian ini menggunakan metode kuantitatif eksplanatori dengan sampel sebanyak 116 pegawai yang bekerja di Badan Pengawasan Keuangan dan Pembangunan. Hasil analisis membuktikan performance management system activities dan structure of performance management systems berpengaruh signifikan dan terbukti positif terhadap kinerja aparatur.
\end{abstract}

\section{Pendahuluan}

Masalah mendasar yang dihadapi oleh banyak pemerintahan di berbagai negara dalam satu dekade terakhir ini adalah kemunduran kepercayaan publik kepada pemerintah (decline of public trust in government) (Silalahi 2011). Kepercayaan publik kepada pemerintah, termasuk institusi-institusi dan agensi-agensi publik sedang mengalami kemunduran di berbagai belahan dunia dan di banyak negara baik negara-negara sedang berkembang dan berkembang, tidak 
terkecuali negara-negara maju. Kemunduran atau rendah kepercayaan publik kepada pemerintahnya juga menjadi masalah mendasar di Indonesia, baik pada era pemerintahan orde baru yang dianggap sebagai era sentralistis dan birokratis, maupun pada era pasca orde baru yang dianggap sebagai era desentralisasi dan demokratis. Krisis kepercayaan publik kepada pemerintah antara lain terkait dengan maraknya kasus korupsi yang dilakukan pejabat pemerintah maupun berbagai layanan publik yang diberikan oleh pemerintah tidak sesuai dengan harapan publik.

Banyak faktor yang dapat mendorong peningkatan kinerja aparatur pemerintah. Menurut Hanim (2002) dalam penelitiannya mengatakan faktor yang mendorong kinerja aparatur pemerintah yang diantaranya adalah struktur organisasi. Struktur organisasi disini diukur melalui kesesuaian struktur organisasi dengan dasar hukumnya, tata kerja organisasi, dan penyelesaian tugas aparat lain. Menurut Kim (2005) kinerja aparatur pemerintah dipengaruhi oleh kepuasan pekerjaan mereka, komitmen yang kuat terhadap organisasi, dan motivasi yang tinggi untuk melayani masyarakat.

Penelitian ini berfokus pada pengaruh karakteristik sistem manajemen kinerja terhadap kinerja aparatur pemerintah. Ruky (2002) menyatakan pengelolaan dan pengembangan seseorang adalah tujuan sistem manajemen kinerja. Dengan melaksanakan sistem manajemen kinerja yang baik, organisasi dapat mengetahui dan mengidentifikasi pelatihan apa saja yang harus diberikan kepada karyawan untuk membantu mencapai standar prestasi yang sudah ditetapkan. Ricci (2016) membagi karakteristik sistem manajemen kinerja menjadi empat kategori, yaitu: purpose of the performance management system, performance measures, performance management system activities, structure of performance management systems. Penelitian ini akan berfokus pada performance management system activities dan structure of performance management systems karena dianggap karakteristik tersebut melekat pada organisasi.

Dalam penelitian ini aparatur pemerintah yang dijadikan sebagai sampel penelitian adalah Kantor Perwakilan Badan Pengawasan Keuangan dan Pembangunan (BPKP) Jawa Timur. Berdasarkan Peraturan Presiden Republik Indonesia Nomor 192 Tahun 2014 Tentang Badan Pengawasan Keuangan dan Pembangunan, BPKP merupakan aparat pengawasan intern pemerintah yang berada dibawah presiden dan bertanggung jawab kepada presiden. Kantor Perwakilan BPKP Jawa Timur dipilih karena berdasarkan Laporan Kinerja Kantor Perwakilan BPKP Jawa Timur dengan nomor LKIN-7/PW13/2017, BPKP Jawa Timur memiliki rencana meningkatkan atau mengembangkan kompetensi Sumber Daya Manusia dalam rangka meningkatkan capaian kinerja. Penelitian ini dilakukan untuk melihat apakah karakteristik sistem manajemen kinerja berpengaruh dan dapat meningkatkan kinerja aparatur di Kantor Perwakilan BPKP Jawa Timur. Berdasarkan pada permasalahan tersebut, maka pertanyaan penelitian ini adalah sebagai berikut. (1) Apakah performance management system 
activities berpengaruh terhadap kinerja aparatur? (2) Apakah structure of performance management systems berpengaruh terhadap kinerja aparatur? Hasil penelitian ini juga diharapkan dapat memberikan kontribusi praktis khususnya pada Kantor Perwakilan Badan Pengawas Keuangan dan Pembangunan Jawa Timur untuk menerapkan sistem manajemen kinerja yang efektif sebagai alat bantu manajemen dalam memotivasi dan mengevaluasi kinerja aparatur.

\section{Tinjauan Pustaka}

\subsection{Institutional Theory}

Teori institusional didasarkan pada pemikiran untuk bertahan, organisasi harus dapat meyakinkan publik atau masyarakat bahwa organisasi adalah entitas yang sah (legitimate) dan layak didukung (Meyer \& Rowan 1977). Teori institusional berpendapat bahwa organisasi yang mengutamakan legitimasi akan memiliki kecenderungan untuk menyesuaikan diri pada harapan eksternal atau harapan sosial dimana organisasi berada (Ashworth et al. 2009). Organisasi publik yang cenderung untuk memperoleh legitimasi akan cenderung memiliki kesamaan atau isomorfisme (isomorphism) dengan organisasi publik lain (DiMaggio \& Powell 1983). DiMaggio \& Powell (1983) mengatakan isomorfisme adalah proses yang mendorong satu unit dalam suatu populasi untuk menyerupai unit lain dalam menghadapi kondisi lingkungan yang sama. Proses yang mendorong organisasi untuk menjadi mirip atau homogen dengan organisasi yang ditiru disebut dengan isomorphic pressures (DiMaggio \& Powell 1983).

Implikasi institutional theory terhadap penelitian ini yaitu menjelaskan bahwa organisasi pemerintah harus didukung oleh berbagai elemen. Tujuan yang ditetapkan oleh organisasi harus selaras dengan harapan eksternal atau harapan sosial dimana organisasi tersebut berada. Kinerja yang dihasilkan oleh aparatur menjadi salah satu bukti bahwa organisasi layak untuk didukung. Organisasi dapat melakukan upaya guna meningkatkan kinerja aparatur. Performance management system activities menjadi salah satu upaya yang dapat dilakukan oleh organisasi. Aktivitas tersebut dapat berupa penetapan tujuan, review, feedback, pelatihan, program pengembangan pegawai, dan rewarding.

\subsection{Goal Setting Theory}

Locke (1990) menyatakan bahwa niat untuk mencapai tujuan merupakan sumber motivasi kerja yang utama. Goal setting theory merupakan teori yang menyatakan bahwa tujuan-tujuan yang spesifik dan sulit, dengan umpan balik, menghasilkan kinerja yang baik 
(Locke dan Latham 1990). Berdasarkan definisi tersebut, maka goal setting theory memberikan arahan upaya-upaya yang harus dilakukan oleh organisasi untuk meningkatkan kinerja sumber daya manusia dalam organisasi tersebut. Organisasi sektor publik sebagai satu organisasi yang memberikan pelayanan kepada masyarakat harus mempunyai kemampuan untuk meningkatkan kinerja aparatur guna peningkatan pelayanan terhadap masyarakat. Organisasi sektor publik dalam melakukan upaya peningkatan kinerja harus dapat memotivasi aparatur untuk mengeksplorasi seluruh kemampuan terbaik yang dimiliki oleh tiap aparatur.

Implikasi goal setting theory terhadap penelitian yaitu menjelaskan bahwa penetapan tujuan yang merupakan bagian dari performance management system activities dapat meningkatkan kinerja aparatur. Tujuan yang sulit dan spesifik, dengan adanya umpan balik maka akan menghasilkan kinerja yang baik. Tujuan yang sudah ditetapkan akan menjadi stimulus bagi aparatur untuk meningkatkan kinerja. Penetapan tujuan yang jelas akan memotivasi aparatur untuk mengeluarkan seluruh kemampuan mereka, sehingga terjadi peningkatan kinerja pada tiap aparatur.

\subsection{Performance Management System Activities}

Manajemen kinerja mengacu pada berbagai aktivitas yang dilakukan organisasi dengan tujuan meningkatkan kinerja individu dan unit kerja (DeNisi 2000). Aktivitas yang sesuai antara lain penetapan tujuan, sistem penilaian, strategi reward, skema pelatihan, dan rencana karier (Roberts 2001). Kinicki et al. (2013) menyatakan tahapan pertama pada aktivitas sistem manajemen kinerja adalah penetapan tujuan. Penetapan tujuan merupakan tahapan penting sebab penetapan tujuan menentukan standar kinerja dan pondasi pencapaian kinerja. Tahap kedua adalah evaluasi terkait perilaku dan kinerja. Pada tahap ini dibutuhkan feedback kinerja dan pelatihan guna kesuksesan di masa depan. Feedback yang efektif merupakan kunci dari aktivitas manajemen kinerja (Greve 2010) dan membantu organisasi meningkatkan kinerja (Kinicki et al. 2004). Ricci (2016) menyatakan indikator terkait aktivitas-aktivitas sistem manajemen kinerja sebagai berikut: (1) pembinaan; (2) feedback; (3) pengakuan; (4) penetapan tujuan; (5) identifikasi pelatihan yang dibutuhkan; dan (6) pengembangan karier.

\subsection{Structure of Performance Management Systems}

Struktur sistem manajemen kinerja menginformasikan desain dan bentuk dari sistem manajemen kinerja (Ricci 2016). Hidayati (2014) menyatakan pelaksanaan manajemen kinerja harus dipandang sebagai sebuah sistem yang berhubungan dengan bagian-bagian lain dari sistem yang lebih luas. Bacal (2001) menyatakan bahwa manajemen kinerja harus berhubungan dengan perencanaan strategis dan arah organisasi, proses anggaran keuangan, 
perencanaan pengembangan karyawan, dan program-program peningkatan motivasi seperti tingkat gaji, imbalan dan promosi. Ricci (2016) menyatakan indikator dari structure of performance management systems sebagai berikut: (1) jumlah review formal kinerja; (2) jumlah review informal kinerja; (3) keselarasan tujuan; (4) hubungan yang jelas antara sistem manajemen kinerja dengan sistem rewards; (5) sumber feedback; dan (6) partisipasi dalam pengambilan keputusan.

\subsection{Kinerja Aparatur}

Sedarmayanti (2011) menjelaskan kinerja merupakan hasil kerja seorang pekerja, sebuah proses manajemen atau suatu organisasi secara keseluruhan, dimana hasil kerja tersebut harus dapat ditunjukkan buktinya secara konkrit dan dapat diukur. Mustopadidjaja (2002) mengatakan bahwa kinerja pemerintahan yang baik (good government performance) bukan saja memerlukan kebijakan yang baik (good policy), tetapi juga sistem dan proses pelaksanaan kebijakan yang baik (good policy implementation system and process) dan kedua hal tersebut memerlukan sistem administrasi pemerintahan negara yang baik (good public administration system) yang mensyaratkan adanya sumber daya manusia yang baik dan diindahkannya prinsip "the right men and women and the right places". Mahoney (1963) menyatakan indikator dari kinerja adalah sebagai berikut: (1) perencanaan; (2) investigasi; (3) pengkoordinasian; (4) evaluasi; (5) pengawasan; (6) pengaturan staf; (7) negosiasi; dan (8) perwakilan.

\subsection{Pengaruh Performance Management System Activities Terhadap Kinerja Aparatur}

Penelitian ini menguji pengaruh performance management system activities terhadap kinerja aparatur. Teori yang digunakan untuk menjelaskan pengaruh ini adalah goal setting theory (Locke 1990). Goal setting theory memberikan arahan upaya-upaya yang harus dilakukan oleh organisasi untuk meningkatkan kinerja sumber daya manusia dalam organisasi. Aktivitas-aktivitas sistem manajemen kinerja yang diterapkan organisasi digunakan sebagai upaya untuk meningkatkan kinerja aparatur. Aktivitas sistem manajemen kinerja bertujuan untuk meningkatkan prestasi kerja pegawai dengan memberikan kesempatan untuk memenuhi kebutuhan aktualisasi diri dalam rangka pencapaian tujuan organisasi. Aktivitas sistem manajemen kinerja yang diterapkan secara baik akan mendorong pegawai untuk meningkatkan kinerja. Berdasarkan pada paparan diatas maka dirumuskan hipotesis sebagai berikut.

H1: Performance management system activities berpengaruh positif terhadap kinerja aparatur 


\subsection{Pengaruh Structure of Performance Management Systems Terhadap Kinerja Aparatur}

Penelitian ini menguji pengaruh structure of performance management systems terhadap kinerja aparatur. Teori yang digunakan untuk menjelaskan pengaruh ini adalah institutional theory (Meyer dan Rowan 1977). Institutional theory menyatakan untuk mempengaruhi perilaku sosial maka harus memperhatikan bagaimana struktur seperti skema, aturan, norma, dan rutin menjadi bentuk yang otoritatif dan juga bagaimana tindakan tersebut diulang atau direproduksi. Struktur sistem manajemen kinerja yang dibuat organisasi harus memperhatikan jumlah review formal maupun informal, keselarasan tujuan, hubungan yang jelas antara sistem manajemen kinerja dengan sistem rewards, sumber feedback, dan partisipasi dalam pengambilan keputusan. Berdasarkan pada paparan diatas maka dirumuskan hipotesis sebagai berikut.

H2: Performance management system activities berpengaruh positif terhadap kinerja aparatur

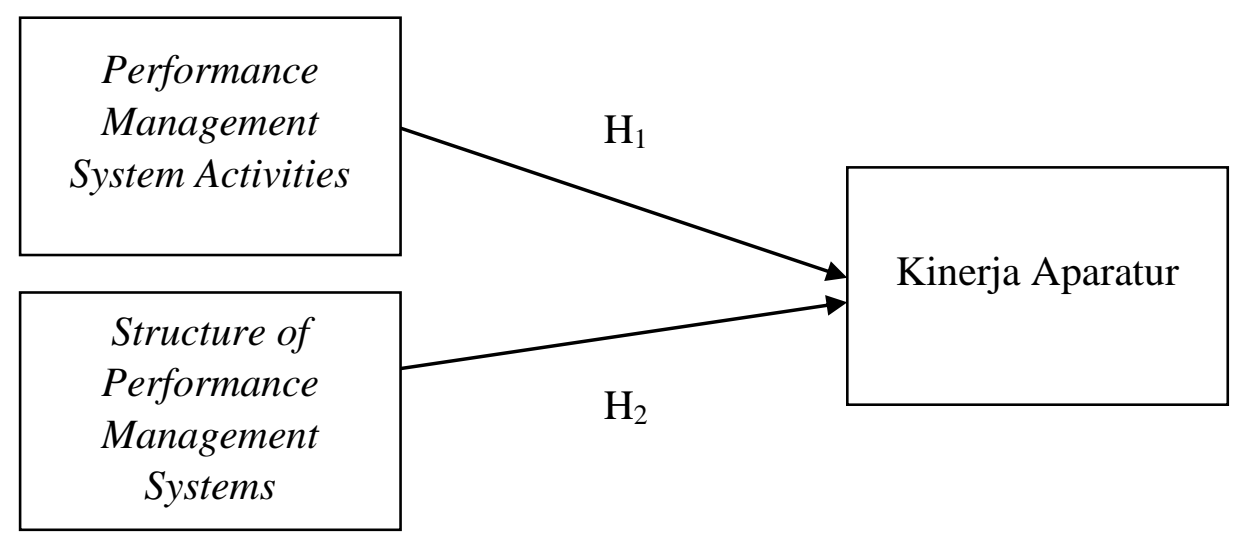

\section{Gambar 1 \\ Kerangka Konseptual}

\section{Metodologi Penelitian}

\subsection{Sampel dan Data Penelitian}

Populasi dalam penelitian ini adalah pegawai yang bekerja pada Kantor Perwakilan BPKP Provinsi Jawa Timur. Data dalam riset ini adalah data primer yang diperoleh dari penyebaran kuesioner kepada para pegawai berdasarkan populasi dan penentuan sampel yang telah ditentukan. Pengumpulan data melalui penyebaran kuesioner diperoleh secara langsung tertuju kepada para pegawai dengan mendatangi Kantor Perwakilan BPKP Provinsi Jawa Timur. 


\subsection{Pengukuran Variabel}

Riset ini menguji pengaruh variabel performance management system activities terhadap kinerja aparatir pemerintah. Variabel performance management system activities diukur dengan menggunakan pertanyaan yang dikembangkan dari Ricci (2016). Instrumen ini terdiri dari enam pertanyaan. Skor yang lebih tinggi menggambarkan performance management system activities yang tinggi. Variabel structure of performance management systems diukur dengan menggunakan pertanyaan yang dikembangkan oleh Ricci (2016). Instrumen ini terdiri dari enam pertanyaan. Skor yang lebih tinggi menggambarkan structure of performance management systems yang tinggi. Variabel kinerja aparatur diukur dengan menggunakan pertanyaan yang dikembangkan dari Mahoney (1963). Instrumen ini terdiri dari delapan pertanyaan. Seluruh teknik pengukuran menggunakan skala Likert dengan nilai antara satu sampai lima. Skor yang lebih tinggi menggambarkan kinerja yang tinggi, sedangkan skor yang rendah menggambarkan kinerja yang rendah.

\section{Analisis dan Pembahasan}

\subsection{Deskripsi Karakteristik Responden}

Data deskriptif yang menggambarkan kondisi responden perlu diperhatikan sebagai informasi tambahan untuk memahami hasil-hasil penelitian. Dari 116 responden jabatan responden sebagian besar adalah auditor madya sebanyak 52 orang atau 44,83\% dari jumlah keseluruhan responden. Jabatan lainnya yaitu selain auditor muda, auditor madya, auditor penyelia, dan pengendali teknis menempati urutan kedua yaitu sebanyak 23 orang atau $19,83 \%$. Jabatan auditor muda menempati urutan ketiga sebanyak 19 orang atau 16,38\%. Jabatan pengendali teknis sebanyak 17 orang atau $14,66 \%$ menempati urutan keempat. Jabatan auditor penyelia sebanyak 5 orang atau 4,31\% menempati urutan terakhir.

Dari 116 responden jenis kelamin responden sebagian besar adalah laki-laki sebanyak 63 orang atau 54,31\% dari total responden. Responden perempuan sebanyak 53 orang atau $45,69 \%$ dari total responden. Dari 116 responden sebagian besar pegawai berlatar belakang pendidikan S1 yaitu sebanyak 62 orang atau 53,45\% dari keseluruhan responden. Pegawai berlatar belakang pendidikan D3 sebanyak 30 orang atau 25,86\%. Pegawai berlatar belakang pendidikan S2 sebanyak 24 orang atau 20,69\%. Dari 116 responden proporsi terbesar responden berusia antara 36 sampai dengan 45 tahun sebanyak 46 orang atau 39,66\%. Responden yang berusia lebih dari 45 tahun sebanyak 38 orang atau 32,76\%. Responden yang berusia 23 sampai dengan 35 tahun sebanyak 32 orang atau 27,59\%. Dari 116 
responden sebagian besar responden yaitu sebanyak 89 orang atau $76,72 \%$ telah memiliki pengalaman yang cukup dibidangnya karena mereka telah bekerja selama lebih dari 15 tahun. Responden yang bekerja selama 11 sampai dengan 15 tahun sebanyak 21 orang atau $18,10 \%$. Responden yang telah bekerja selama 5 sampai dengan 10 tahun sebanyak 6 orang atau $5,17 \%$.

4.2. Uji Validitas dan Uji Reliabilitas Variabel

Tabel 1

Hasil Pengukuran Discriminant Validity

\begin{tabular}{|l|l|}
\hline \multicolumn{1}{|c|}{ Variabel } & Original Sample (0) \\
\hline Kinerja Aparatur Pemerintah & 0,581 \\
\hline Performance Management System Activities & 0,554 \\
\hline Structure of Performance Management Systems & 0,766 \\
\hline
\end{tabular}

Sumber: Olahan data 2018

Seluruh variabel memiliki nilai discriminant validity diatas 0,50. Dari hasil tersebut, dapat disimpulkan bahwa seluruh variabel adalah valid dan dapat memberikan keyakinan.

Tabel 2

Hasil Pengukuran Composite Reliability

\begin{tabular}{|l|l|}
\hline \multicolumn{1}{|c|}{ Variabel } & Original Sample (0) \\
\hline Kinerja Aparatur Pemerintah & 0,917 \\
\hline Performance Management System Activities & 0,880 \\
\hline Structure of Performance Management Systems & 0,929 \\
\hline
\end{tabular}

Sumber: Olahan data 2018

Berdasarkan tabel 4.14 , seluruh variabel memiliki nilai composite reliability lebih besar dari 0,70 . Dari hasil tersebut, dapat disimpulkan bahwa seluruh variabel dalam penelitian adalah reliabel dan dapat diandalkan untuk digunakan dalam uji analisis lebih lanjut.

\subsection{Hasil Uji Model Fit}

Tabel 3

Hasil Uji Model Fit

\begin{tabular}{|l|l|}
\hline APC & 0,$355 ; \mathrm{P}=0,001$ \\
\hline ARS & 0,$398 ; \mathrm{P}<0,001$ \\
\hline AARS & 0,$388 ; \mathrm{P}<0,001$ \\
\hline AVIF & 1,273 \\
\hline
\end{tabular}

Sumber: Data olahan 2018

Berdasarkan hasil olah data pada tabel 3 menunjukkan bahwa model dalam penelitian ini dinyatakan fit. APC, ARS, dan AARS mempunyai $p$-value $\neg$ kurang dari 0,05 . Sedangkan nilai 
dari $\mathrm{AVIF}<3,3$ menunjukkan bahwa tidak ada masalah multicollinearity antara indikator dan variabel yang digunakan.

\subsection{Hasil Uji Inner Model}

Tabel 4

Nilai R-square Adjusted (Adjusted R2)

\begin{tabular}{|c|c|c|}
\hline Variabel Endogen & $\begin{array}{c}\text { Nilai R-square Adjusted } \\
\text { (Adjusted R2) }\end{array}$ & Nilai Q-square (Q2) \\
\hline $\begin{array}{c}\text { Kinerja Aparatur } \\
\text { Pemerintah }\end{array}$ & 0,388 & 0,401 \\
\hline
\end{tabular}

Sumber: Data olahan 2018

Dari tabel 4.16 tersebut, dapat dilihat bahwa kinerja aparat mempunyai nilai R-square Adjusted (Adjusted R2) sebesar 0,388 (38,8\%). Hal ini menunjukkan bahwa variabel kinerja aparatur pemerintah dapat diprediksi oleh performance management system activities dan structure of performance management systems sebesar $38,8 \%$, sementara sisanya $(61,2 \%)$ dapat diprediksi oleh variabel lain yang tidak digunakan dalam penelitian ini. Berdasarkan Q2 dapat disimpulkan bahwa variabel bebas dalam penelitian memiliki validitas prediktif yang baik. Hal ini dikarenakan nilai Q2 lebih besar dari nol.

\subsection{Pengujian Pengaruh Performance Management System Activities dan Structure of Performance Management Systems}

\section{Tabel 5}

Hasil Uji t-statistik Performance Management System Activities Dan Structure of Performance Management Systems Terhadap Kinerja Aparatur Pemerintah

\begin{tabular}{|c|c|c|}
\hline Hubungan Antar Variabel & $\begin{array}{c}\text { Original } \\
\text { Sample (0) }\end{array}$ & p-values \\
\hline $\begin{array}{c}\text { Performance Management System Activities } \rightarrow \text { Kinerja Aparatur } \\
\text { Pemerintah }\end{array}$ & 0,192 & 0,016 \\
\hline $\begin{array}{c}\text { Structure of Performance Management Systems } \rightarrow \text { Kinerja } \\
\text { Aparatur Pemerintah }\end{array}$ & 0,519 & $<0,001$ \\
\hline
\end{tabular}

Sumber: Data olahan 2018

Berdasarkan hasil pada tabel 4.17, maka dapat disimpulkan bahwa performance management system activities dan structure of performance management systems berpengaruh positif dan terbukti signifikan terhadap kinerja aparatur pemerintah. Hal tersebut dapat dilihat dari $p$-values sebesar $<0,05$. Nilai positif pada original sample menunjukkan pengaruh yang searah antara performance management system activities dan structure of performance management systems dengan kinerja aparatur pemerintah. 
Berdasarkan nilai $\mathrm{p}$ values dan nilai original sample untuk melihat pengaruh performance management system activities dan structure of performance management systems terhadap kinerja aparatur pemerintah, maka dapat disumpulkan bahwa variabel performance management system activities dan structure of performance management systems berpengaruh positif dan terbukti signifikan terhadap kinerja aparatur pemerintah. Hal ini menunjukkan bahwa hipotesis satu dan hipotesis dua yang menyatakan performance management system activities dan structure of performance management systems berpengaruh terhadap kinerja aparatur pemerintah terbutki signifikan.

\subsection{Pengaruh Performance Management System Activities Terhadap Kinerja Aparatur Pemerintah}

Hipotesis satu menyatakan bahwa performance management system activities yang dilakukan oleh Kantor Perwakilan BPKP Provinsi Jawa Timur berpengaruh signifikan terhadap kinerja aparatur pemerintah. Hasil dari penelitian ini dengan menggunakan uji statistik menunjukkan bahwa variabel performance management system activities berpengaruh signifikan terhadap kinerja aparatur pemerintah, sehingga $\mathrm{H} 1$ diterima. Dapat disimpulkan bahwa performance management system activities merupakan salah satu faktor penting untuk meningkatkan kinerja aparatur pegawai Kantor Perwakilan BPKP Provinsi Jawa Timur.

Penelitian ini membuktikan bahwa pelaksanaan performance management system activities memiliki peran dan memberikan dampak positif terhadap individu masing-masing, dengan adanya dampak positif tersebut maka akan berdampak terhadap peningkatan kinerja aparatur pemerintah. Adanya performance management system activities seperti pembinaan dan feedback yang baik akan membuat pegawai lebih menikmati pekerjaan dan akan meningkatkan kinerja karena individu tersebut merasakan pemberdayaan dan kepercayaan pada lingkungan kerjanya, merasakan dukungan langsung dari seorang atasan, dan mengerti bagaimana tugas yang diberikan dapat menghasilkan kontribusi besar untuk organisasi.

Performance management system activities juga dapat digunakan untuk memotivasi para aparatur. Aktivitas seperti pengembangan karier dan pengakuan merupakan stimulus untuk memotivasi aparatur dalam meningkatkan kinerjanya mengingat pengakuan merupakan salah satu bentuk penghargaan yang diberikan atas prestasi yang dicapai. Pengakuan yang diberikan akan meningkatkan kebanggaan kepada tiap aparatur dan akan berupaya untuk lebih meningkatkan kinerjanya. 


\subsection{Pengaruh Structure of Performance Management Systems Terhadap Kinerja Aparatur Pemerintah}

Hipotesis dua menyatakan bahwa structure of performance management systems yang dilmiliki oleh Kantor Perwakilan BPKP Provinsi Jawa Timur berpengaruh signifikan terhadap kinerja aparatur pemerintah. Hasil dari penelitian ini dengan menggunakan uji statistic menunjukkan bahwa variabel structure of performance management systems berpengaruh signifikan terhadap kinerja aparatur pemerintah, sehingga H2 diterima. Dapat disimpulkan bahwa structure of performance management systems merupakan salah satu faktor penting untuk meningkatkan kinerja aparatur pegawai Kantor Perwakilan BPKP Provinsi Jawa Timur.

Penelitian ini membuktikan bahwa structure of performance management systems yang dimiliki oleh organisasi dapat memberikan dampak positif terhadap individu masing-masing, dengan adanya sisi positif yang ada dalam masing-masing individu akan berdampak terhadap peningkatan kinerja. Hal yang perlu diperhatikan pada structure of performance management systems antara lain jumlah review formal kinerja, jumlah review informal kinerja, keselarasan tujuan, hubungan yang jelas antara sistem manajemen kinerja dengan sistem rewards, sumber feedback, dan partisipasi dalam pengambilan keputusan.

Review rutin yang dilaksanakan oleh organisasi dapat meningkatkan kinerja aparatur, karena pada dasarnya review bertujuan untuk membantu aparatur dalam menghadapi masalah yang muncul dalam rangka pencapaian sasaran kerja yang sudah ditetapkan. Keselarasan tujuan antara tujuan individu yang ditetapkan dengan tujuan organisasi akan membantu aparatur mengerti bagaimana pekerjaan yang dilakukan dapat memberikan kontribusi pada organisasi. Kepuasan aparatur akan meningkat apabila aparatur mengetahui bahwa kontribusi yang diberikan ikut serta dalam memajukan organisasi.

Sistem rewards yang diterapkan organisasi harus berdasarkan pencapaian kinerja aparatur. Rewards yang diberikan kepada aparatur dapat memotivasi untuk menghasilkan kinerja yang baik. Rewards yang berdasarkan kinerja dapat menjadi stimulus kepuasan dan kebanggaan aparatur sehingga diharapkan aparatur akan terus meningkatkan kinerja. Partisipasi dalam pengambilan keputusan akan memberikan peran dan keterlibatan lebih kepada tiap aparatur. Adanya peran dan keterlibatan lebih dalam pengambilan keputusan dapat menimbulkan suatu kepuasan dan motivasi dalam dirinya yang membuat aparatur merasa dihargai karena diberi wewenang dalam proses pengambilan keputusan. Hal ini membuat aparatur merasa nyaman pada organisasi yang dia tempati, dengan adanya sikap seperti itu maka dapat meningkatkan kinerja aparatur. 


\section{Kesimpulan, Keterbatasan, dan Saran}

\subsection{Kesimpulan}

Penelitian ini meneliti tentang pengaruh performance management system activities dan structure of performance management systems terhadap kinerja aparatur pemerintah. Berikut ini adalah simpulan dari hasil penelitian ini:

1. Variabel performance management system activities berpengaruh positif dan terbukti signifikan terhadap kinerja aparatur pemerintah. Hasil dari penelitian ini mendukung penelitian yang dilakukan oleh Ricci (2016), Kasenda (2013), dan Maulidi (2013).

2. Variabel structure of performance management systems berpengaruh positif dan terbukti signifikan terhadap kinerja aparatur pemerintah. Hasil dari penelitian ini mendukung penelitian yang dilakukan oleh Ricci (2016), Averina (2013), Agusti (2012), dan Jusuf (2013).

\subsection{Saran}

Berdasarkan hasil penelitian dan pembahasan yang telah dijelaskan sebelumnya, maka dapat disarankan:

1. Penelitian selanjutnya diharapkan dapat mengembangkan sendiri instrument untuk pengukuran kinerja aparatur yang lebih baik, untuk menghindari terjadinya bias.

2. Periode pengamatan dan jumlah institusi yang diteliti perlu diperbanyak untuk mendapatkan nilai generalisasi yang lebih besar.

\section{Daftar Pustaka}

Ashworth, R., Boyne, G., R, \& Delbridge. (2009). Escape From The Iron Cage? Organizational Change and Isomorphic Pressures in the Public Sector. Journal of Public Administration Research and Theory.

Bacal, R. (2001). Performance Management. Jakarta: Gramedia Pustaka Utama.

DeNisi, A. S. (2000). Performance Appraisal and Performance Management. San Fransisco: Jossey-Bass.

DiMaggio, P. J., \& Powell, W. W. (1983). The Iron Cage Revisited: Institutional Isomorphism and Collevtive Rationality in Organizational Fields. American Sociological Review.

Greve, H. R. (2010). Positional Rigidity: Low Performance and Resource Acquisition in Large and Small Firms. Strategic Management Journal.

Hidayati, I. (2014). Analisis Penerapan Sistem Manajemen Kinerja Berbasis Kompetensi. Jurnal Administrasi Bisnis. 
Kim, S. (2005). Individual-Level Factors and Organizational Performance in Government Organization. Journal of Public Administration Research and Theory, 245-261.

Kinicki, A., \& Kreitner, R. (2004). Organizational Behavior Sixth Edition. Boston: McGraw Hill.

Kinicki, A., \& Kreitner, R. (2013). Organizational Behavior Tenth Edition. New York: McGraw Hill.

Locke, E. A., \& Latham, G. P. (1990). A Theory of Goal Setting \& Task Performance. New Jersey: Prentice Hall, Englewood Cliffs.

Meyer, J., \& Rowan, B. (1977). Institutionalized Organizations Formal Structure as Myth and Ceremony. The American Journal of Sociology.

Ricci, L. (2016). The Impact of Performance Management System Characteristics on Perceived Effectiveness of the System and Engagement.

Roberts, I. (2001). Reward and Performance Management. Edinburgh: Pearson.

Ruky, A. S. (2006). Sistem Manajemen Kinerja. Jakarta: Gramedia Pustaka Utama

Sedarmayanti. (2011). Manajemen Sumber Daya Manusia, Reformasi Birokrasi dan Manajemen Pegawai Negeri Sipil. Bandung: Refika Aditama.

Silalahi, U. (2011). Kepercayaan Publik kepada Pemerintah Orde Baru. Jurnal IImu Administrasi Negara Volume 11 Nomor 2, 167-179. 